\title{
BIO-INCIDENCE OF Mycobacterium avium SUBSPECIES paratuberculosis IN THE PASTEURIZED LIQUID MILK, FLAVOURED MILK AND MILK POWDER COMMERCIALLY SOLD BY LEADING MARKET BRANDS IN INDIA
}

\author{
Manju Singh ${ }^{1,2 \#}$, Shoor Vir Singh ${ }^{1 *}$, Saurabh Gupta $^{1 \#}$, Kundan Kumar Chaubey $^{1}$, \\ Jagdip Singh Sohal ${ }^{2}$, Kuldeep Dhama ${ }^{3}$
}

\footnotetext{
${ }^{1}$ Animal Health Division, Central Institute for Research on Goats, Mathura 281122, Uttar Pradesh, India

${ }^{2}$ AIMT and AIB, Amity University Rajasthan, Jaipur, 303007, Rajasthan, India

${ }^{3}$ Division of Pathology, Indian Veterinary Research Institute, Izatnagar, 243122, Uttar Pradesh, India
}

Received - October 27, 2017; Revision - December 20, 2017; Accepted - January 04, 2018

Available Online - February 20, 2018

DOI: http://dx.doi.org/10.18006/2018.6(1).188.203

\author{
KEYWORDS \\ Mycobacterium avium \\ subspecies paratuberculosis \\ Indigenous plate ELISA \\ Dot ELISA \\ Latex agglutination test \\ Fluorescent antibody test
}

\begin{abstract}
In this study, 133 milk samples (100 commercial liquid milk, 19 flavored milk and 14 milk powder) made from pasteurized milk by 10 leading commercial brands were purchased from the markets in Mathura and Agra districts of South Uttar Pradesh in North India. These milk samples were screened to estimate 'bio-incidence' of Mycobacterium avium subspecies paratuberculosis (MAP) using multiple tests; 3 antibody \{Indigenous ELISA (i_ELISA), dot ELISA (d_ELISA) and Latex agglutination test (LAT) $\}$ and 3 antigen (microscopy, Indirect fluorescent antibody test (i_FAT) and IS900 PCR . Of 133 samples screened, 42.8, 58.6, 9.0, 27.0, 49.6 and 42.8\% were positive for MAP in microscopy, i_FAT, IS900 PCR, i_ELISA, d_ELISA, and LAT, respectively. i_FAT was most sensitive followed by d_ELISA, LAT, microscopy, i_ELISA and IS900 PCR. In general, i_FAT, d_ELISA, LAT and microscopy were significantly superior to i_ELISA and IS900 PCR for estimating bio-incidence of MAP in milk samples. High bio-incidence of MAP in food items of mass consumption (liquid milk, flavoured milk and milk powder) made from pasteurized milk and freely sold in local markets by leading commercial brands emphasized the need for the immediate implementation of programs for the control of MAP in domestic livestock. MAP, the cause of incurable Johne's disease is endemic in
\end{abstract}

* Corresponding author

E-mail: shoorvir.singh@gmail.com; shoorvir_singh@rediffmail.com (Shoor Vir Singh)

Peer review under responsibility of Journal of Experimental Biology and Agricultural Sciences.

Production and Hosting by Horizon Publisher India [HPI] (http://www.horizonpublisherindia.in/).

All rights reserved.
All the article published by Journal of Experimental Biology and Agricultural Sciences is licensed under a Creative Commons Attribution-NonCommercial 4.0 International License Based on a work at www.jebas.org.

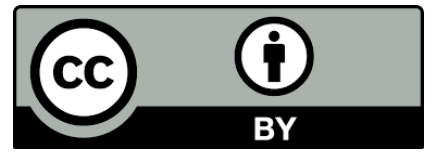


the domestic livestock population of the country. In order to prevent the human infection through consumption of commercially marketed milk and milk products (flavoured milk and milk powder), it is essential to control bio-load of MAP in the domestic livestock population at the National level.

\section{Introduction}

Mycobacterium avium subspecies paratuberculosis (MAP), the cause of chronic enteritis called Johne's disease (JD) in domestic livestock, has also been associated with number of incurable, auto-immune diseases (Inflammatory Bowel disease or Crohn's disease, etc.) in human beings (McFadden et al., 1992; Bull et al., 2003; Abubakar et al., 2007; Scanu et al., 2007; Cirone et al., 2007; Naser et al., 2014; Banche et al., 2015; McNees et al., 2015). Live bacilli (MAP) have been recovered from milk and milk products made from laboratory scale and commercial size pasteurization facilities for liquid milk in Czech Republic, UK, USA and India (Grant et al., 1996; Shankar et al., 2010). Country has huge population ( $>500$ million) of domestic livestock, endemically infected with MAP (Singh et al., 2014; Rawat et al., 2014). We have reported high to very high bio-incidence of MAP in the raw milk (individual animals and pooled milk) of domestic livestock (Singh et al., 2007; Shankar et al., 2010; Singh et al., 2014). At 155.5 million tonnes (MT) of milk produced in 201617, India is leading milk producer in the world (Annual Report, DADF, 2016-2017) and approximately $40.0 \%$ of milk is pasteurized, predominantly by state cooperatives, multi-national companies, or government dairy plants (India in business, Investment and technology promotion and energy security, Delhi: Ministry of External Affairs, Government of India, 2008) for the preparation of various milk products. Traditionally raw milk also used as base for many Ayurvedic medicines (Tursun et al., 2015). Un-like, M.bovis, the cause of bovine TB, MAP is able to resist pasteurization (Lund et al., 2002) and live bacilli have been cultured from commercial pasteurized milk supplies (Grant et al., 2002), retailed pasteurized milk (Singh et al., 2009; Paolicchi et al., 2012;Eftekhari \& Mosavari, 2016) and milk products like milk powder (Hruska et al., 2011; Botsaris et al., 2016; Acharya et al., 2017) including retail cheese (Ikonomopoulos et al., 2005; Raghuvanshi et al., 2014; Eftekhari \& Mosavari, 2016). Retailed cheese, powdered milk and ice-creams are important milk products that are being consumed by large percentage of human population both in India and globally. Consumption of milk and milk products \{liquid pasteurized milk (for drinking purpose), milk powder (as infant supplement), cheese (as top-up and main ingredient of highly popular pizza) and ice-creams (as sweet dish during personal, family, official and group celebrations and marriage ceremonies etc.) made from pasteurized milk\} without boiling has increased the risk of infection manifold. Popularity of milk and milk products (flavoured milk and milk powder) is not restricted to urban areas but also reached in rural areas. Since, MAP is not in-activated during pasteurization, therefore routine daily consumption of these milk products has led to increased compromise on 'public health concerns' and milk as important vehicle of some of the dangerous 'food borne pathogens' like MAP, in the country (Singh et al., 2016d) and globally (Cirone et al., 2007; Eltholth et al., 2009; Patel \& Shah, 2011). In-activated MAP bacilli can also be a risk for number of health problems due to structural components (Grant, 2006). Despite direct effect on human health, consumption of milk and milk / dairy products \{flavoured milk and powdered infant formula (PIF) \} laden with MAP bacilli are not legally banned by any country in the world. Many food safety authorities in UK advised government to adopt precautionary steps to minimize the entry of MAP into the human food chain (Grant, 2006).

Today milk and dairy products received most attention as vehicles for transmission of MAP, an important food borne pathogen, since MAP is secreted in the milk of infected animals. Raw milk may also be contaminated with fecal material during milking. Though number of studies in developed countries reported presence of MAP bacilli or DNA in the raw milk samples (Stabel et al., 2002; Stephan et al., 2002), but studies are extremely limited in other parts of the world. MAP infection, the cause of incurable chronic enteritis is endemic in nearly 500 million population of domestic livestock in the country (Singh et al., 2010; Singh et al., 2013b; Singh et al., 2014; Chaubey et al., 2016), however, information on the bio-incidence of MAP in commercially retailed pasteurized milk and milk products in the country is almost non-existent (Shankar et al., 2010; Raghuvanshi et al., 2014).

Bio-safety of food items and bio-incidence of MAP in milk and milk products is matter of intense research in developed countries and a battery of tests have been used to demonstrate the presence of MAP. Though, culture is 'Gold standard' test but takes long time (6-8 weeks). PCR based assays rapidly confirm this fastidious slow-growing bacilli in clinical samples (Millar et al., 1996; Singh et al., 2013a; Singh et al., 2014; Nielsen \& Toft, 2014; Garg et al., 2015). In our laboratory besides traditionally used microscopy, we have developed and standardized number of diagnostic assays like Indigenous ELISA kit (i_ELISA), indirect fluorescent antibody test (i_FAT), indigenous dot-ELISA (d_ELISA), IS900 PCR and latex agglutination test (LAT) for the 
screening of milk and milk products and to estimate bio-incidence of MAP (Sharma et al., 2008; Singh et al., 2016a; Singh et al., 2016b; Singh et al., 2016c). Present study first time used both traditional and newly developed and standardized serological and molecular tests (microscopy, IS900 PCR, i_ELISA, d_ELISA, LAT and i_FAT) to estimate bio-incidence of MAP in liquid pasteurized milk and milk products (flavoured milk and milk powder) made from pasteurized milk and sold by 10 leading commercial market brands in Mathura and Agra districts of South UP in North India.

\section{Materials and Methods}

\subsection{Collection and processing of milk samples:}

Commercial food items of 'mass consumption' \{liquid pasteurized milk and milk products (flavoured milk and milk powder) made from 'pasteurized milk'\} were screened to estimate the bioincidence of MAP using six tests. For this purpose 133 commercial milk samples (100 liquid milk from eight market brands, 19 flavoured milk from five market brands and 14 milk powder from two market brands) belonged to 10 leading commercial market brands (Amul, Ananda, Nestle India, Gyan, Mother dairy, MTR, Namaste India, Nova, Paras and Sanchi) were purchased from local markets in Mathura (Farah and Kosi) and Agra districts of South Uttar Pradesh. First time milk samples were screened using whole milk as 'test sample' without any processing. In our previous studies, milk samples were first processed by centrifugation, wherein each milk samples was separated in to whey, fat and sediment layers and three fractions of each milk samples were processed independently. Samples were screened both by antigen $\{$ (microscopy, i_FAT and IS900 PCR) and antibody (i_ELISA, d_ELISA and LAT) \} detection tests to estimate bio-incidence of MAP. Each of the 133 milk samples were screened six times by each of the six diagnostic tests (3 antigen and 3 antibody detection tests). IS1311 PCR_RE and milk culture were performed on limited number of IS900 PCR positive samples, to know the 'bio-type profile' (molecular epidemiology) and demonstrate live MAP bacilli in commercial milk samples. In the present study each 'milk sample' was treated as representing 'single animal' and a sample positive in any of the six tests was considered positive for 'bio-incidence' of MAP.

Approximately, 10-12 ml of milk (liquid milk and flavoured milk) and 2.0 grams of milk powder / dairy creamer (homogenized in $10-12 \mathrm{~mL}$ of autoclaved distilled water) were collected from sachet / packet / container and stored. Two milli-liters of these samples were used as 'test sample' and was sufficient to perform all the six tests. 'Test samples' (liquid milk, flavoured milk and homogenized milk powder) were subjected to microscopy, i_FAT and IS900 to detect MAP bacilli and LAT, i_ELISA and d_ELISA tests to detect anti-MAP lacto-globulins (antibodies).

\subsection{Microscopy}

Smears were prepared from $20 \mu \mathrm{l}$ of commercial milk samples, heat fixed, stained by Ziehl Neelsen (ZN) staining (Singh et al., 2008) and examined under oil immersion $(\times 100)$ for acid-fast bacilli (AFB) indistinguishable to MAP (Figure 1).

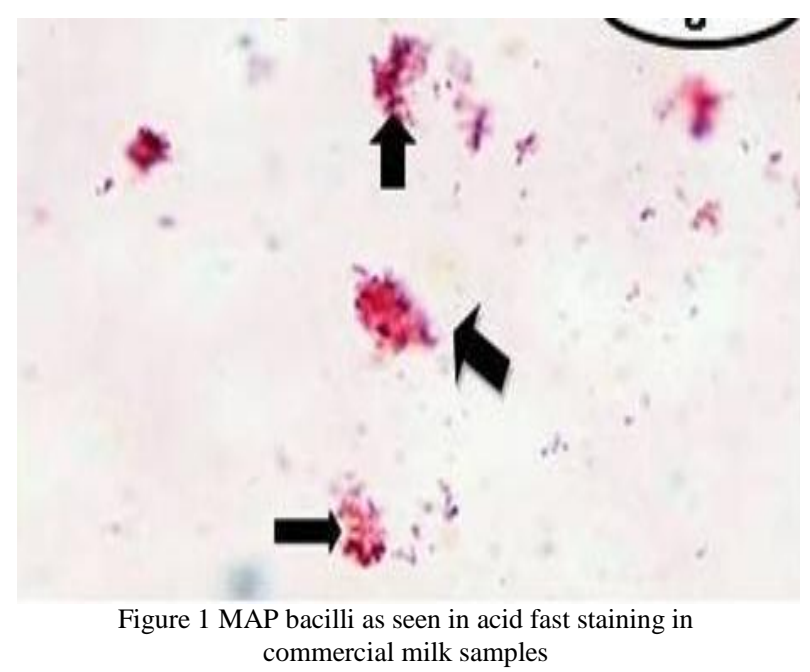

\subsection{Indirect Fluorescent Antibody Test (i_FAT)}

Test was performed as per Singh et al. (2016a). Briefly, smears were prepared on clean slides from $(20 \mu \mathrm{l}$ commercial milk) samples, air dried at room temperature and heat fixed. Slides were dipped in solution of $30.0 \% \mathrm{H}_{2} \mathrm{O}_{2}$ in $90.0 \%$ methanol (3:7 ratio) and incubated for 10 minutes at $37^{\circ} \mathrm{C}$, followed by second dipping in phosphate-citrate buffer $(2.1 \%$ citric acid and $3.56 \%$ disodium hydrogen phosphate in $100 \mathrm{ml}$ triple distilled water, $\mathrm{pH}-5$ ) and were heated to boiling in microwave for 30 seconds ( 15 cycles) with rest of 20 seconds after each heating cycle (total time 10 minutes). Slides were then air dried at room temperature. Then primary antibody (whey as control in ratio of 1:4 and serum in ratio of 1:50) in serum dilution buffer (1\% BSA in PBST) was added on the slides. Slides were incubated for 1 hour at $37^{\circ} \mathrm{C}$ in BOD incubator, followed by washing of slides in $1 \mathrm{X}$ PBS (3 times). Anti-species secondary antibody (FITC conjugate) was added in the ratio 1:750 in $1 \mathrm{X}$ PBS (pH-7.6). Slides were incubated in dark for 1 hour at $37^{\circ} \mathrm{C}$ followed by washing of slides 5 times in $1 \mathrm{X}$ PBS in dark. Slides were air dried in dark at room temperature. Finally, slides were mounted with glycerine and covered with cover slip and then observed immediately under fluorescent microscope. One smear prepared from the heat killed MAP culture was used as control for the comparison of results. Slides positive for MAP infection exhibited green fluorescence under fluorescent microscope (Figure 2). 

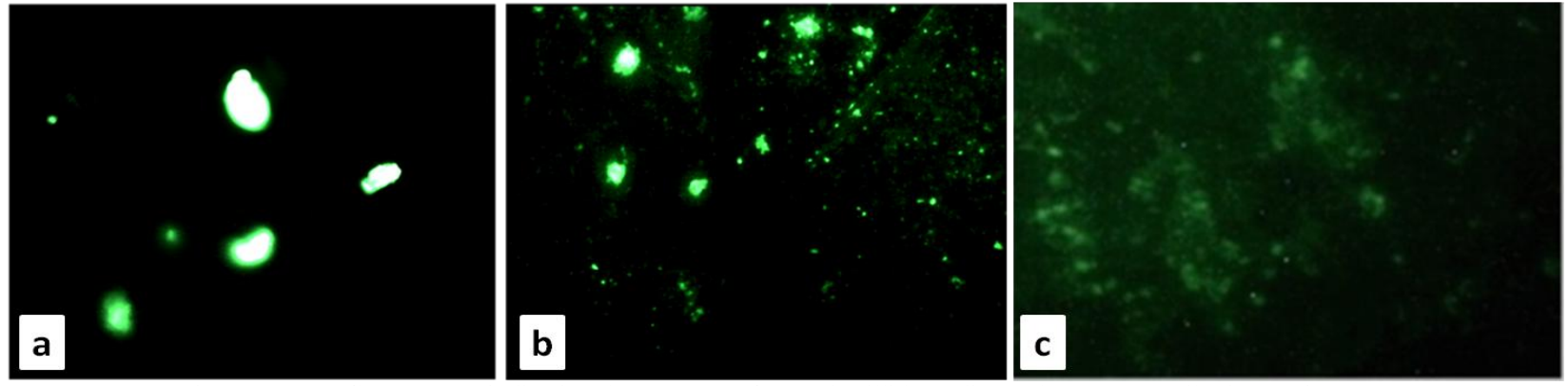

Figure 2 Green fluorescence indicating the presence of MAP bacilli by Indirect Fluorescent antibody test (i_FAT).

a: Positive control; b: Commercial milk sample; c: Negative control

\subsection{DNA Isolation}

DNA isolation from commercial milk was carried out as per Van Soolingen et al. (1991) with some modifications. Briefly, $500 \mu \mathrm{l}$ commercial milk sample, $100 \mu \mathrm{l}$ of lysis buffer $(50 \mathrm{mM} \mathrm{NaCl}, 125$ mM EDTA, $50 \mathrm{mM}$ Tris-HCl; $\mathrm{pH}$ 7.6) was added and incubated at RT for $15 \mathrm{~min}$. After that $100 \mu \mathrm{l}$ of $24 \%$ sodium dodecyl sulfate (SDS) was added and incubated at RT for $10 \mathrm{~min}$, followed by heating at $80^{\circ} \mathrm{C}$ for $10 \mathrm{~min}$. Then, $32.5 \mu \mathrm{l}$ of proteinase $\mathrm{K}$ $(10 \mathrm{mg} / \mathrm{ml})$ was added to above sample and incubated at $55^{\circ} \mathrm{C}$ for 2 hrs., followed by addition of $115 \mu \mathrm{l}$ of $5 \mathrm{M} \mathrm{NaCl}$ and $93 \mu \mathrm{CTAB}-$ $\mathrm{NaCl}$ with proper mixing and incubated at $65^{\circ} \mathrm{C}$ for $30 \mathrm{~min}$. Equal volume of phenol:chloroform:isoamyl alcohol (25:24:1) was added to sample and centrifuged at $15800 \mathrm{~g}$ for $5 \mathrm{~min}$. After centrifugation, resulting aqueous phase from sample was transferred to sterilized eppendrof tube and DNA was precipitated by adding 0.8 volume of chilled iso-propanol and kept at $-20^{\circ} \mathrm{C}$ for 2 hours. DNA was pelleted out by centrifugation at $15800 \mathrm{~g}$ for $10 \mathrm{~min}$. at $4^{\circ} \mathrm{C}$ and then supernatant was discarded. Finally, pellet was washed with $500 \mu \mathrm{l}$ of $70 \%$ ethanol and re-suspended in $30 \mu \mathrm{l}$ TE buffer/ nuclease free water and stored at $-20^{\circ} \mathrm{C}$.

\subsection{IS900 PCR}

DNA isolated from commercial milk samples, was subjected to specific IS900 PCR using $150 \mathrm{C}$ and 921 primers of Vary et al. (1990). Presence and yield of specific PCR product (229bp) was considered as positive for MAP infection (Figure 3). DNA isolated from MAP culture was taken as control for comparison of results.

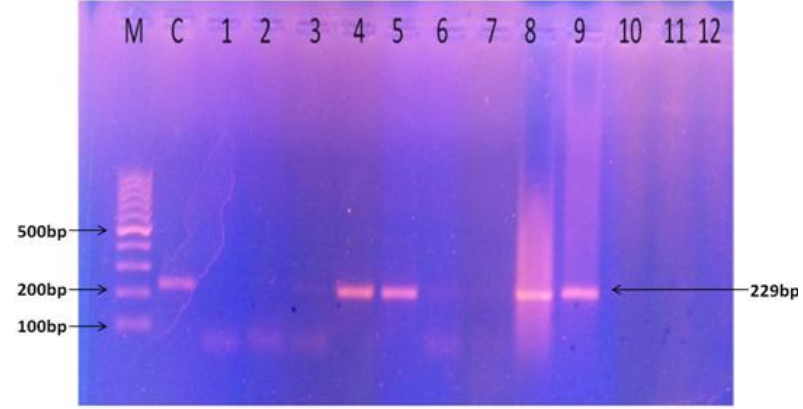

Figure 3 Agarose gel electrophoresis of PCR products obtained by IS900 PCR (A) performed on commercial milk samples [Lane M: 100bp DNA ladder; Lane C: MAP DNA (positive control, 229bp); Lane 1: Negative control and Lane 2-12: Commercial milk test samples]

\subsection{IS1311 PCR and restriction endonuclease analysis (IS1311 PCR_REA)}

IS1311 PCR of IS900 PCR positive DNA samples were performed using M56 and M119 primers as per Sevilla et al. (2005). Resultant PCR products (608bp) were subjected to electrophoresis (2\% Agarose gel stained with Ethidium bromide). Amplicons that comigrated at $608 \mathrm{bp}$ were taken as positive. The 608bp IS1311 PCR products were restricted by restriction endonuclease digestion with HinfI and MseI enzymes (Fermentas) for $1.5 \mathrm{hrs}$ by incubating at $37^{\circ} \mathrm{C}$ (Sevilla et al., 2005). Fragments (amplicons) were separated on $3.0 \%$ agarose gel and genotypes were identified on the basis of fragment migration patterns (Whittington et al., 2001) (Figure 4).

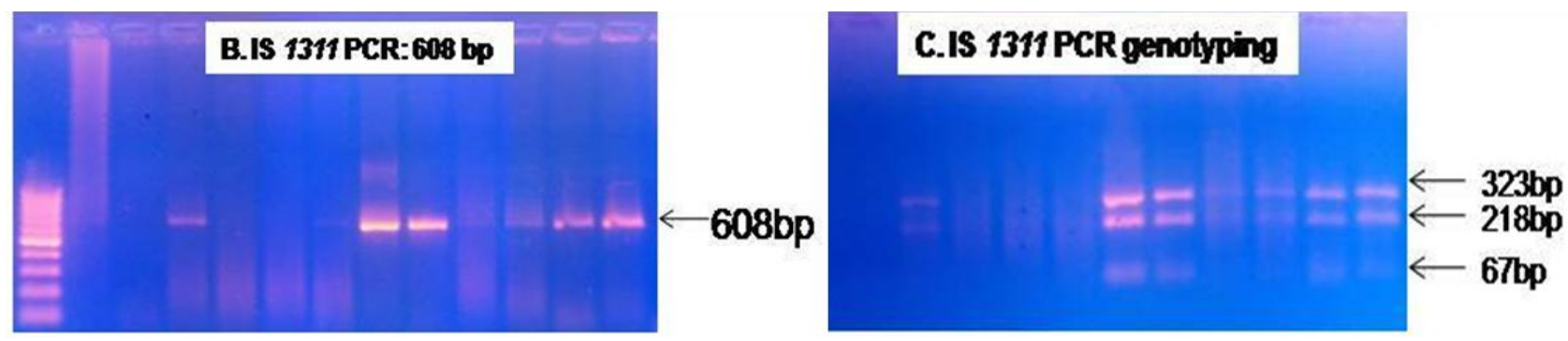

Figure 4 Molecular bio-typing of IS900 positive MAP DNA by IS1311 PCR (B) and IS1311 PCR-REA analysis (C)

Journal of Experimental Biology and Agriculture Science http://www.jebas.org 


\subsection{Indigenous ELISA test}

Test was performed as per Singh et al. (2016b) and instead of whey, commercial milk sample (liquid milk and flavoured milk) and homogenized milk powder were used as test sample. Briefly, each well of flat bottom 96 well ELISA plate was coated with 0.1 $\mu \mathrm{g}$ of protoplasmic antigen in $100 \mu \mathrm{l}$ of carbonate-bicarbonate buffer, (pH 9.6) per well and incubated at $4{ }^{\circ} \mathrm{C}$ overnight. Plates were washed thrice with PBST (1X PBS with $0.05 \%$ Tween 20) followed by blocking in $100 \mu \mathrm{l}$ of $3.0 \%$ skimmed milk in $1 \mathrm{X}$ PBS, incubated for one hour at $37^{\circ} \mathrm{C}$. Plates were washed three times with PBST and then $100 \mu$ of commercial milk diluted in PBST with $1.0 \%$ BSA in ratio of 1:2 was added as sample in duplicate wells and incubated for $2 \mathrm{hrs}$ at $37^{\circ} \mathrm{C}$. Plates were washed thrice followed by addition of $100 \mu \mathrm{l}$ of optimally diluted rabbit antibovine (1:6000 in 1X PBS) / caprine (1:5000 in $1 \mathrm{X}$ PBS) conjugate and again incubated for one hour at $37^{\circ} \mathrm{C}$. Finally after five times washing, $100 \mu$ l of freshly prepared OPD substrate was added and incubated till colour developed (3-5 min) at $37^{\circ} \mathrm{C}$. Absorbance was read at $450 \mathrm{~nm}$ in ELISA reader (i-Mark microplate reader, Biorad). Whole milk from weak and culture positive and healthy and culture negative goat were used as positive and negative controls, respectively. Optical densities (OD) values were transformed and expressed as sample-to-positive (S/P) ratios (Collins, 2002).

\subsubsection{Analysis of OD values}

Sample to positive ratios were derived to estimate corresponding status of JD in goats was determined as per Collins (2002). Samples in low positive (LP), positive (P) and strong positive (SP) categories in sample to positive ratios were considered positive for MAP infection (Collin, 2002).

$\mathrm{S} / \mathrm{P}$ ratio value $=[($ Sample OD - Negative OD $) /($ Positive OD Negative OD)].

\subsection{Dot- ELISA}

Test was performed as per Singh et al. (2016b). Briefly, tips of 12 legged immune-diffusion combs (Advanced Microdevices pvt. ltd., Ambala, Haryana) fixed with nitrocellulose membrane were coated with $1 \mu \mathrm{l}(2 \mu \mathrm{g}$ of sPPA in $1 \mu \mathrm{l}$ of carbonate-bi-carbonate buffer, $\mathrm{pH}$ 9.6) of sPPA spot in middle of nitrocellulose paper and incubated for 2 hours at $37^{\circ} \mathrm{C}$. Combs were dipped in blocking solution (3.0\% skimmed milk powder in $1 \mathrm{X}$ PBS) for $1 \mathrm{hr}$ at $37^{\circ} \mathrm{C}$. After washing in PBST combs were dipped in test samples (100 $\mu$ l commercial milk in 1:2 dilution in $1 \%$ BSA in $1 \mathrm{X}$ PBST) for one $\mathrm{hr}$ followed by again washing. Further combs were incubated with $200 \mu \mathrm{l}$ of rabbit anti-bovine (1:3000 in 1X PBS) / caprine (1:3000 in $1 \mathrm{X}$ PBS) HRP conjugate solution at $37^{\circ} \mathrm{C}$ for $30 \mathrm{~min}$. Finally, combs were dipped in $200 \mu \mathrm{l}$ of 3, 3'Diaminobenzidine (6mg / $10 \mathrm{ml}$ of $1 \mathrm{X}$ PBS), at room temperature till development of colour (1-2 min) (Figure 5). Once the spot was visible combs were dipped in water to stop the reaction. Milk positive and negative controls used in the study were confirmed by IS900 PCR and microscopy, were used on two legs of each comb to assist in reading of test samples.

\subsection{Latex Agglutination test}

\subsubsection{Preparation of latex beads}

Commercial milk samples (n-133) were screened using LAT as per Singh et al. (2016c). Briefly, MAP antigen coated latex beads were prepared using $10 \mu \mathrm{l}$ of polystyrene latex beads $(3.0 \mu \mathrm{m}$ mean size, Sigma Aldrich). Beads were washed four times in distilled water and re-suspended in $20 \mu \mathrm{l}$ of $0.5 \mathrm{M}$ glycine saline buffer (1.4 gm glycine, $0.07 \mathrm{gm}$ Sodium Hydroxide, $1.7 \mathrm{gm}$ Sodium Chloride, $0.1 \mathrm{gm}$ Sodium Azide in $100 \mathrm{~mL}$ of triple distilled water) ( $\mathrm{pH}-8.6)$, then $20 \mu \mathrm{l}$ of antigen $(4 \mathrm{mg} / \mathrm{mL})$ was added and incubated for 3 hours at $37^{\circ} \mathrm{C}$ in shaker incubator. Mixture was centrifuged at $5000 \mathrm{rpm}$ for $10 \mathrm{~min}$ and after aspirating the supernatant, mixture was re-suspended in blocking

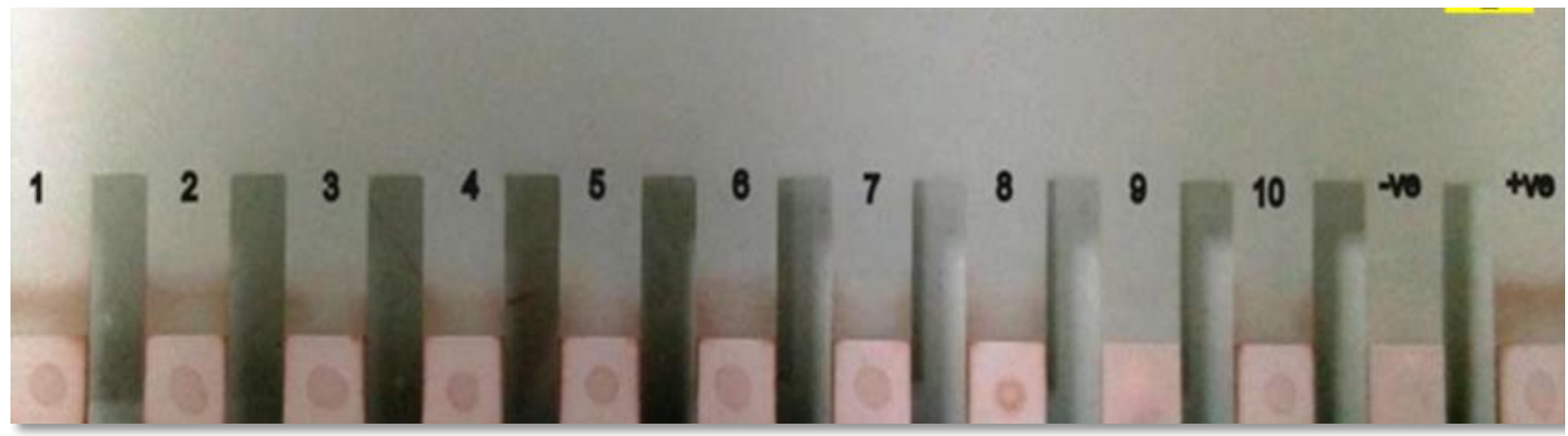

Figure 5 Dot-ELISA screening of commercial milk samples (1-10) showing presence of MAP antibodies as positive brown dot; +ve: Positive control (brown dot); -ve: Negative control (no brown dot) 


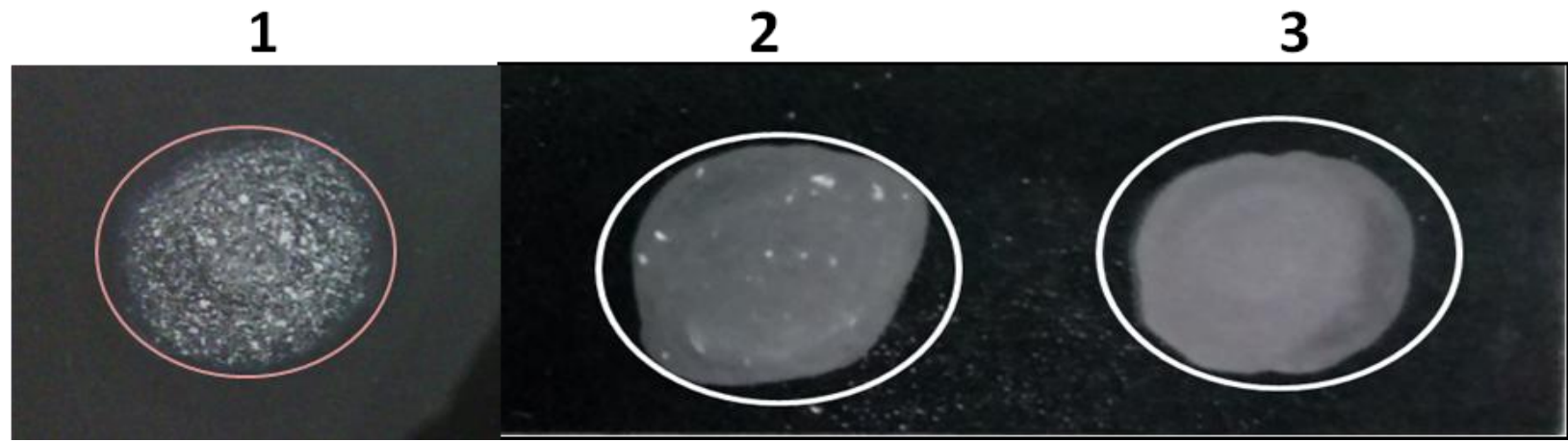

Figure 6 Latex Agglutination test result for the detection of MAP antibodies in commercial milk samples. 1: Milk positive control; 2: Positive commercial milk sample; 3: Negative commercial milk sample.

buffer (1\% BSA in 1X PBS) and mixed in shaker incubator for 45 $\min$ at $37^{\circ} \mathrm{C}$. Finally beads were washed twice in $1 \mathrm{X}$ PBS

\section{9b. Test proper:}

LAT was performed by mixing $4 \mu \mathrm{l}$ of commercial milk sample with $2 \mu 1$ of antigen coated latex beads with tip of a pipette on a glass slide. Slide was shaken gently for $2 \mathrm{~min}$, and milk sample was considered positive, if agglutination was observed within 2 min and negative if no agglutination was observed in $2 \mathrm{~min}$ (Figure 6). Whole milk from weak and culture positive and healthy and culture negative goats were used as positive and negative controls, respectively.

\subsection{Statistical Analysis}

To estimate statistical significance between the two tests, 'Mc Nemar's test' and 'kappa agreement' were applied by Graph Pad software, USA. Sensitivity and specificity of the tests was measured by Med-Calc software, Belgium.

\section{Results and Discussion}

First time in India, a large number $\{133$ commercial milk samples (liquid milk, flavoured milk and milk powder) \} were screened by six tests combinations and $63.1 \%(84 / 133)$ were positive (each sample positive in one or more than one tests) for the bioincidence of MAP. Screening by 'Indigenous ELISA kit', revealed $27.0 \%(36 / 133)$ samples as positive $(15.7 \%$ in positive and $11.2 \%$ in low positive categories). Stabel \& Lambertz (2004), stated that MAP is shed by infected animals primarily in the feces but is also shed in the milk at much lower levels. Therefore, unlike screening of serum samples, where samples in low positive category were considered negative, were taken as positive in milk i_ELISA kit. Whereas, using microscopy, i_FAT, IS900 PCR, d_ELISA and LAT, 42.8, 58.6, 9.0, 49.6 and 42.8\% milk samples were positive, respectively (Table 1 and 2). By six tests combinations, 4.5 (6/133) and 36.8\% (49/133) milk samples were
Table 1 Bio-incidence of MAP in commercial pasteurized milk samples of leading Indian brands sold in the local markets using 'Indigenous milk ELISA kit'

\begin{tabular}{|c|c|c|c|c|c|c|}
\hline \multicolumn{7}{|c|}{ i_ELISA kit, \% (n) } \\
\hline Categories & $\begin{array}{c}\text { Strong } \\
\text { Positive } \\
\text { (SP) }\end{array}$ & $\begin{array}{l}\text { Positive } \\
\text { (P) }\end{array}$ & $\begin{array}{l}\text { Low } \\
\text { Positive } \\
\text { (LP) }\end{array}$ & $\begin{array}{c}\text { Suspected } \\
\text { (S) }\end{array}$ & $\begin{array}{l}\text { Negative } \\
(\mathrm{N})\end{array}$ & $\begin{array}{c}\text { False } \\
(\mathrm{F})\end{array}$ \\
\hline Sub-total & Nil & $\begin{array}{c}15.7 \\
(21 / 133)\end{array}$ & $\begin{array}{c}11.2 \\
(15 / 133)\end{array}$ & $\begin{array}{c}11.2 \\
(15 / 133)\end{array}$ & $\begin{array}{c}60.9 \\
(81 / 133)\end{array}$ & $\begin{array}{c}0.7 \\
(1 / 133)\end{array}$ \\
\hline $\begin{array}{c}\text { Total } \\
\text { (n-133) }\end{array}$ & Nil & & $\begin{array}{l}27.0 \\
133)\end{array}$ & & $\begin{array}{l}\text { N-72.9 } \\
(97 / 133)\end{array}$ & \\
\hline
\end{tabular}

Figures in parenthesis are numbers, Total samples (n) -133, N Negative, P - Positive

positives and negatives, respectively. This indicated that 6 and 49 milk samples were positive and negatives (i.e., not detected by any of the six tests), for MAP infection, respectively. However, 12.7 (17/133), 24.1 (32/133), 5.2 (7/133), 10.5 (14/133) and 6.0\% (8/133) samples were positive in five, four, three, two and one tests combinations, respectively. The $41.3 \%$ (55/133) samples were positive in four, five and six tests combinations. While $15.7 \%$ (21/133) were positive in two and three tests combinations and only $6.0 \%$ were positive in single test (Table 3 ). Thus a total of $57.1 \%$ (76/133) commercial milk samples were positive for MAP at least in two and more than two tests combinations can be safely considered as confirmed positive for MAP infection. Table 3, column 1 and 2 showed that 6 and 49 samples were either detected by all 6 tests or not detected in any of the 6 tests, respectively, i.e., perfect positive or negative. This large bio-load of MAP in pasteurized milk was 'true bio-incidence' and not due to 'false positivity' of the diagnostic tests, as many may believe due to high 'bio-incidence' of MAP in commercial milk samples marketed in India. In this study majority of samples were positive and one sample was positive in multiple tests; six, five, four, three and two test combinations. Only 8 samples $(6.0 \%)$ were positive by one test. Of these 8 milk samples positive in one test either microscopy or 
i_FAT (antigen detection tests) was enough to justify these were 'definitely positive'. This is very essential for large number of people

Table 2a: Screening of commercial pasteurized milk samples (liquid milk, flavoured milk and milk powder) from popular Indian market brands sold in the local markets to estimate bio-incidence of MAP using multiple tests

\begin{tabular}{|c|c|c|c|c|c|c|c|c|}
\hline \multirow{2}{*}{$\begin{array}{l}\text { Samples } \\
\text { (n) }\end{array}$} & \multicolumn{8}{|c|}{ Positives \% (n) } \\
\hline & Micro. & i_FAT & $\begin{array}{l}\text { IS900 } \\
\text { PCR }\end{array}$ & i_ELISA & d_ELISA & LAT & Culture & Bio-typing \\
\hline Liquid milk (100) & $\begin{array}{c}41.0 \\
(41 / 100)\end{array}$ & $\begin{array}{c}60.0 \\
(60 / 100)\end{array}$ & $\begin{array}{c}9.0 \\
(9 / 100)\end{array}$ & $\begin{array}{c}29.0 \\
(29 / 100)\end{array}$ & $\begin{array}{c}55.0 \\
(55 / 100)\end{array}$ & $\begin{array}{c}49.0 \\
(49 / 100)\end{array}$ & 2 (RA) & $\begin{array}{c}6.0 \\
(06 / 100)\end{array}$ \\
\hline Flavoured milk (19) & $\begin{array}{c}31.5 \\
(6 / 19)\end{array}$ & $\begin{array}{c}42.1 \\
(8 / 19)\end{array}$ & $\begin{array}{c}00 \\
(00 / 19)\end{array}$ & $\begin{array}{c}15.7 \\
(3 / 19)\end{array}$ & $\begin{array}{c}21.0 \\
(4 / 19)\end{array}$ & $\begin{array}{c}10.5 \\
(2 / 19)\end{array}$ & (RA) & 00 \\
\hline Milk powder (14) & $\begin{array}{c}71.4 \\
(10 / 14) \\
\end{array}$ & $\begin{array}{c}71.4 \\
(10 / 14) \\
\end{array}$ & $\begin{array}{c}21.4 \\
(3 / 14)\end{array}$ & $\begin{array}{c}28.5 \\
(4 / 14)\end{array}$ & $\begin{array}{c}50.0 \\
(7 / 14)\end{array}$ & $\begin{array}{c}42.8 \\
(6 / 14)\end{array}$ & (RA) & $\begin{array}{c}14.2 \\
(02 / 14)\end{array}$ \\
\hline Total (133) & $\begin{array}{c}42.8 \\
(57 / 133)\end{array}$ & $\begin{array}{c}58.6 \\
(78 / 133)\end{array}$ & $\begin{array}{c}9.0 \\
(12 / 133)\end{array}$ & $\begin{array}{c}27.0 \\
(36 / 133)\end{array}$ & $\begin{array}{c}49.6 \\
(66 / 133)\end{array}$ & $\begin{array}{c}42.8 \\
(57 / 133)\end{array}$ & 2 (RA) & $\begin{array}{c}6.0 \\
(08 / 133)\end{array}$ \\
\hline
\end{tabular}

Total samples (n) -133, LAT- Latex Agglutination Test, i_ELISA- Indigenous ELISA kit,

Micro. - Microscopy, i_FAT- Indirect Fluorescent Antibody Test, RA- Results Awaited.

Table 2b: Profile of leading market brands of commercial pasteurized milk samples (liquid milk, flavoured milk) and milk powder (made from pasteurized milk), bio-incidence and bio-type profile of MAP based on multiple tests screening

\begin{tabular}{|c|c|c|c|c|c|c|}
\hline \multirow{2}{*}{ Sn } & \multicolumn{2}{|c|}{ Milk Brands } & \multicolumn{2}{|c|}{ Commercial Milk } & \multirow{2}{*}{$\begin{array}{c}\text { Positives } \\
\%(n)\end{array}$} & \multirow{2}{*}{$\begin{array}{l}\text { Bio-typing } \\
\%(n)\end{array}$} \\
\hline & Name & Code & Type & (n) & & \\
\hline \multirow{3}{*}{1.} & \multirow{3}{*}{ Amul } & \multirow{3}{*}{ A } & Liquid milk & 60 & $61.6(37)$ & $5.0(3)$ \\
\hline & & & Flavoured milk & 05 & $40.0(02)$ & 00 \\
\hline & & & Milk powder & 05 & $80.0(04)$ & 00 \\
\hline 2. & Ananda & B & Liquid milk & 04 & $50.0(02)$ & 00 \\
\hline 3. & Nestle, India & $\mathrm{C}$ & Milk powder & 09 & $77.7(07)$ & $22.2(02)$ \\
\hline 4. & Gyan & $\mathrm{D}$ & Liquid milk & 05 & $100.0(05)$ & 00 \\
\hline \multirow{2}{*}{5.} & \multirow{2}{*}{ Mother dairy } & \multirow{2}{*}{$\mathrm{E}$} & Liquid milk & 11 & $72.7(08)$ & 00 \\
\hline & & & Flavoured milk & 03 & $33.3(01)$ & 00 \\
\hline 6. & MTR & $\mathrm{F}$ & Flavoured milk & 05 & $40.0(02)$ & 00 \\
\hline 7. & Namaste India & G & Liquid milk & 03 & $66.6(02)$ & 00 \\
\hline 8. & Nova & $\mathrm{H}$ & Liquid milk & 05 & $100.0(05)$ & $20.0(01)$ \\
\hline \multirow{2}{*}{9.} & \multirow{2}{*}{ Paras } & \multirow{2}{*}{ I } & Liquid milk & 07 & $42.8(03)$ & $14.2(01)$ \\
\hline & & & Flavoured milk & 04 & $50.0(02)$ & 00 \\
\hline \multirow{2}{*}{10.} & \multirow{2}{*}{ Sanchi } & \multirow{2}{*}{$\mathrm{J}$} & Liquid milk & 05 & $50.0(02)$ & $20.0(01)$ \\
\hline & & & Flavoured milk & 02 & $100.0(02)$ & 00 \\
\hline \multicolumn{4}{|c|}{ Total samples } & 133 & $63.1(84)$ & $6.0(08)$ \\
\hline
\end{tabular}

Jounnatof Experimentat Biotrgy and Agriculture Science

http://www.jebas.org 
Table 2bi: Screening of commercial pasteurized 'liquid milk' samples of leading market brands for estimating bio-incidence and bio-type profile of MAP using multiple tests

\begin{tabular}{|c|c|c|c|c|c|}
\hline \multirow[t]{2}{*}{ Sn } & \multicolumn{2}{|c|}{ Milk Brands } & \multirow{2}{*}{$\begin{array}{c}\text { Liquid Milk } \\
\text { (n) }\end{array}$} & \multirow{2}{*}{$\begin{array}{c}\text { Positives } \\
\%(n)\end{array}$} & \multirow{2}{*}{$\begin{array}{c}\text { Bio-typing } \\
\%(n)\end{array}$} \\
\hline & Name & Code & & & \\
\hline 1. & Amul & A1 & 60 & $61.6(37)$ & $5.0(3)$ \\
\hline 2. & Ananda & B & 04 & $50.0(02)$ & 00 \\
\hline 3. & Gyan & D & 05 & $100.0(05)$ & 00 \\
\hline 4. & Mother dairy & E1 & 11 & $72.7(08)$ & 00 \\
\hline 5. & Namaste India & $\mathrm{G}$ & 03 & $66.6(02)$ & 00 \\
\hline 6. & Nova & $\mathrm{H}$ & 05 & $100.0(05)$ & $20.0(01)$ \\
\hline 7. & Paras & I1 & 07 & $42.8(03)$ & $14.2(01)$ \\
\hline 8. & Sanchi & $\mathrm{J} 1$ & 05 & $40.0(02)$ & $20.0(01)$ \\
\hline \multicolumn{3}{|c|}{ Total samples } & 100 & $64.0(64)$ & $6.0(06)$ \\
\hline
\end{tabular}

n- Number of samples; * 'Indian Bison Type' bio-type

Table 2bii: Screening of commercial pasteurized 'flavoured milk' samples of leading market brands for estimating bio-incidence and bio-type profile of MAP using multiple tests

\begin{tabular}{|c|c|c|c|c|c|}
\hline \multirow[t]{2}{*}{ Sn } & \multicolumn{2}{|c|}{ Milk Brands } & \multirow{2}{*}{$\begin{array}{l}\text { Flavoured Milk } \\
\qquad(\text { n) }\end{array}$} & \multirow{2}{*}{$\begin{array}{c}\text { Positives } \\
\text { \% (n) }\end{array}$} & \multirow{2}{*}{$\begin{array}{c}\text { Bio-typing } \\
\%(n)\end{array}$} \\
\hline & Name & Code & & & \\
\hline 1 & Amul & $\mathrm{A} 2$ & 05 & $40.0(02)$ & 00 \\
\hline 2 & Mother dairy & E2 & 03 & $33.3(01)$ & 00 \\
\hline 3. & MTR & $\mathrm{F}$ & 05 & $40.0(02)$ & 00 \\
\hline 4. & Paras & I2 & 04 & $40.0(02)$ & 00 \\
\hline \multirow[t]{2}{*}{5.} & Sanchi & $\mathrm{J} 2$ & 02 & $100.0(02)$ & 00 \\
\hline & \multicolumn{2}{|c|}{ Total samples } & 19 & $47.3(09)$ & $00(00)$ \\
\hline
\end{tabular}

n- Number of samples

Table 2biii: Screening of commercial pasteurized 'milk powder' samples of leading market brands for estimating bio-incidence and bio-type profile of MAP using multiple tests

\begin{tabular}{|c|c|c|c|c|c|}
\hline \multirow[t]{2}{*}{ Sn } & \multicolumn{2}{|c|}{ Milk Brands } & \multirow{2}{*}{$\begin{array}{c}\text { Milk powder } \\
\text { (n) }\end{array}$} & \multirow{2}{*}{$\begin{array}{c}\text { Positives } \\
\%(n)\end{array}$} & \multirow{2}{*}{$\begin{array}{c}\text { Bio-typing } \\
\%(n)\end{array}$} \\
\hline & Name & Code & & & \\
\hline 1 & Amul & A3 & 05 & $80.0(04)$ & 00 \\
\hline 2 & Nestle, India & $\mathrm{C}$ & 09 & $77.7(07)$ & $22.2(02)$ \\
\hline \multicolumn{3}{|c|}{ Total samples } & 14 & $78.5(11)$ & $14.2(02)$ \\
\hline
\end{tabular}

n- Number of samples.

Journal of Experimental Biology and Agriculture Science http://www.jebas.org 
Table 3: Comparison of six tests for the detection of bio-incidence of MAP in commercial milk samples of leading Indian market brands sold in the local cities of Agra and Mathura

\begin{tabular}{|c|c|c|c|c|c|c|c|c|c|c|c|c|c|c|c|c|c|c|}
\hline \multirow{2}{*}{ Tests } & \multicolumn{17}{|c|}{ Test Combinations } & \multirow[t]{2}{*}{ Total } \\
\hline & 1 & 2 & 3 & 4 & 5 & 6 & 7 & 8 & 9 & 10 & 11 & 12 & 13 & 14 & 15 & 16 & 17 & \\
\hline Microscopy & + & - & + & + & + & + & - & + & + & - & - & + & - & - & + & - & - & $\begin{array}{c}42.8 \\
(57 / 133) \\
\end{array}$ \\
\hline i_FAT & + & - & + & + & + & + & + & + & + & - & + & + & + & - & - & + & - & $\begin{array}{c}58.6 \\
(78 / 133)\end{array}$ \\
\hline IS900 PCR & + & - & + & + & - & - & - & - & + & - & - & - & - & - & - & - & - & $\begin{array}{c}9.0 \\
(12 / 133) \\
\end{array}$ \\
\hline i_ELISA & + & - & + & - & + & - & + & + & - & + & - & - & - & + & - & - & - & $\begin{array}{c}27.0 \\
(\mathbf{3 6} / 133) \\
\end{array}$ \\
\hline d_ELISA & + & - & + & + & + & + & + & + & . & + & + & - & + & + & - & - & + & $\begin{array}{c}49.6 \\
(66 / 133)\end{array}$ \\
\hline LAT & + & - & - & + & + & + & + & - & - & + & + & - & - & - & - & - & - & $\begin{array}{c}42.8 \\
(57 / 133) \\
\end{array}$ \\
\hline Total $-\mathbf{n}$ & 6 & 49 & 1 & 3 & 13 & 18 & 12 & 2 & 2 & 1 & 4 & 10 & 3 & 1 & 2 & 4 & 2 & $\begin{array}{c}\mathbf{6 3 . 1} \\
(84 / 133)\end{array}$ \\
\hline
\end{tabular}

Total samples (n):133; (-): Denotes the negative samples in individual test of that particular test combination; (+): Denotes the positive samples in individual test of that particular test combination; 1-17: Maximum permutation and combinations possible in 6 test regimen; Total-n: Represents only total positive samples in that particular test combination.

in India viewing the high 'bio-incidence' of MAP in milk and milk products made from pasteurized milk may look with an eye of suspicion. Our experience of 33 years in MAP research tell us that the samples negative in six tests may be taken as 'apparently non-infected' and not negative, in a scenario, where bio-incidence of MAP has been reported to be very high in domestic livestock (Singh et al., 2014) and this study again reports high bio-incidence in milk samples. The present finding 'negative' status (or freedom from MAP infection) may not be true and may be very transient phase or temporary thing or even may be mis-leading sometimes, since in these studies our results of high bio-incidence of MAP are based on 'one time sampling' and that too in a chronic insidious infection like MAP. Results of testing of each milk sample six times with six different tests, gives us opportunity to choose the tests as per the purpose (for screening or confirmatory test) and resources or as per the sensitivity and specificity of the tests in estimating the bio-incidence of MAP infection.

Of the 6 tests used, i_FAT (58.6\%) was most sensitive followed by d_ELISA (49.6\%), microscopy (42.8\%), LAT (42.8\%), i_ELISA (27.0\%) and IS900 PCR (9.0\%). Overall the sensitivity of i_FAT, d_ELISA, microscopy and LAT was comparable and superior to i_ELISA and IS900 PCR for the detection of bio-incidence of MAP in commercial milk samples. Sensitivity of i_ELISA and IS900 PCR was moderate and poor, respectively. i_ELISA was moderately sensitive since, titre of anti-MAP lacto-globulins was low in milk samples. Low sensitivity of PCR was due to lower concentration of MAP bacilli in milk samples. Cumulative results of six tests showed that bio-incidence of MAP was very high (63.1\%, $84 / 133$ ) in commercial milk samples. Sample positive in any one of the six tests was considered as positive. The reasons for such high bio-incidence of MAP in milk samples was due to high secretion of MAP by domestic livestock in milk, colostrum and feces, in-ability of pasteurization temperature to inactivate MAP, transmission of MAP from one generation to next generation by semen (Khol et al., 2010), during pregnancy (Whittington \& Windsor, 2009) and through milk (Gilardoni et al., 2016; Grant et al., 2017) and colostrums (Pithua et al., 2011), absence of 'indigenous diagnostic kits, high cost of imported kits, poor sensitivity of imported kits, lack of priority for control, absence of control strategies, vaccines etc. (Bastida \& Juste, 2011). Only $6.0 \%$ of the milk samples were positive exclusively in one test $(1.5 \%$ each in microscopy and d_ELISA and $3.0 \%$ in i_FAT), which is very small percent and may not have much impact on the overall results or findings. Here too, chances of false positive in i_FAT and microscopy were rare.

Statistically kappa and two-tailed $\mathrm{p}$ values were calculated for the six tests used for the screening of 133 commercial milk samples (Table 4). In antigen tests, i_FAT and IS900 PCR, the agreement was good and fair, respectively with respect to microscopy. Using antibody tests, both d_ELISA and LAT had moderate agreement with respect to i_ELISA. With respect to microscopy, i_FAT and IS900 PCR had sensitivity of 96.4 and $21.0 \%$, respectively. Specificity of i_FAT and IS900 PCR was 69.7 and $100.0 \%$, respectively with respect to microscopy. However, with respect to i_ELISA, sensitivity of d_ELISA and LAT was 100 and $88.8 \%$, respectively and specificity was 69.1 and $74.2 \%$, respectively (Table 4). All six tests were compared statistically and strength of agreement was estimated to be 'moderate' for d_ELISA with respect to i_ELISA with a kappa value of 0.547. For LAT with respect to i_ELISA, strength of agreement was 'moderate' with 
kappa value of 0.533 . The strength of agreement was 'good' for i_FAT with respect to microscopy with a kappa value of 0.633 (Table 4).

In the present study, 4.5 and $36.8 \%$ milk and milk products were positive and negative in all the 6 tests, respectively. However, $63.1 \%$ samples were positive in either one or more than one test. Independently in single test, only 4 (3.0\%), 2 (1.5\%) and 2 (1.5\%) commercial milk samples were positive in i_FAT, microscopy and d_ELISA, respectively. Since specificity of i_FAT is high, therefore $3.0 \%$ milk samples positive exclusively will be definitely positive for MAP infection. Similarly, two samples positive in microscopy exclusively, will also be positive, since this test is well standardized in our laboratory for past 32 years. Therefore, at the most two (1.5\%) samples positive in d_ELISA exclusively may be taken either way (positive or negative) that means $61.6 \%$ samples of commercial milk, still positive, which is high percentage. This high level of infection leaves very little doubt on the positivity of the two samples in d_ELISA. Of the 6 tests used, i_FAT was most sensitive followed by d_ELISA, microscopy, LAT, p_ELISA and IS900 PCR. Overall, i_FAT, d_ELISA, microscopy and LAT were significantly superior to i_ELISA and IS900 PCR for the detection of MAP infection in commercial milk samples. Comparatively, i_ELISA kit was moderately sensitive. Therefore, depending on the requirement (convenience, cost, resources, expertise) any of the four tests (i_FAT, microscopy, d_ELISA, LAT), including i_ELISA kit, can be employed for the screening of milk and milk product either singly or in combination of two, three or four. In the three antibody detection tests, 27.0, 49.6 and $42.8 \%$ samples were positive in i_ELISA, d_ELISA and LAT respectively. Of the three antibody detection tests, d_ELISA was most sensitive followed by LAT and i_ELISA. However d_ELISA and LAT were significantly superior as compared to i_ELISA. In the three antigen / bacili detection tests, 42.8, 58.6 and $9.0 \%$ samples were positive by i_FAT, microscopy and IS900 PCR, respectively. In antigen detection tests, i_FAT was significantly superior, specific and sensitive followed by microscopy (also significantly superior) and IS900 PCR. Therefore depending on the need, convenience and purpose any of the four tests, i_FAT, d_ELISA, LAT and microscopy in that order may be the test of choice for the detection of MAP in milk and milk products (Table 2 and 3). However, since i_FAT, d_ELISA, LAT and microscopy are qualitative tests, where dependence on the expertise of worker is critical. Therefore, i_ELISA being quantitative test which can be repeated shall be better option for mass screening of milk samples.

In general, tests focussing on antigen (Microscopy, i_FAT and IS900 PCR) were significantly superior as compared to antibody based (i_ELISA, d_ELISA and LAT) tests. This is contrary to our findings in 'raw milk samples' (personal communications), wherein 'antibody detection tests' were superior to 'antigen detection' tests. In the pasteurization milk samples used in this study, low positivity in anit-body detection tests may be due to the de-naturation of milk proteins (Lacto-albumin) during heating of milk to $72^{\circ} \mathrm{C}$ for pasteurization. Comparison of liquid milk, flavoured milk and milk powder using three antigen detection tests (Microscopy, i_FAT and IS900 PCR) showed that significantly higher number of milk samples were positive in milk powder made from pasteurized milk, followed by pasteurized liquid milk and flavoured milk samples. This pattern was same in all the three tests. However, in antibody detection tests (i_ELISA, d_ELISA and LAT), percent positive milk samples were highest in liquid milk followed by milk powder and flavoured milk. Though, the difference in percent positivity was not significant in liquid milk and milk powder. Whereas, percent positivity was significantly lower in flavoured milk as compared to liquid milk and milk powder. The antibody detection tests proves the incidence of MAP in the domestic livestock population from which milk was supplied therefore, led to the high and significant MAP antibodies titre in commercial milk products. Comparison of antigen and antibody detection tests in the liquid milk, flavoured milk and milk powder showed that in liquid milk, highest percent positivity was slightly higher in liquid milk as compared to flavoured milk and i_FAT was most sensitive followed by d_ELISA, LAT, microscopy, i_ELISA and IS900 PCR. However, in flavoured milk, highest percent positivity was in i_FAT, followed by microscopy, d_ELISA, i_ELISA and LAT. Whereas, none of the

Table 4: Sensitivity and specificity of diagnostic tests for the screening of commercial milk samples of leading market brands (n-133)

\begin{tabular}{|c|c|c|c|c|c|c|c|}
\hline Tests Type & $\begin{array}{c}\text { Diagnostic } \\
\text { Test }\end{array}$ & Comparative Test & $\begin{array}{l}\text { Two tailed } \\
\text { P value }\end{array}$ & $\begin{array}{c}\text { Kappa } \pm \\
\text { SE }\end{array}$ & $\begin{array}{l}\text { Strength of } \\
\text { agreement }\end{array}$ & $\begin{array}{c}\text { Sensitivity } \\
(\%)\end{array}$ & $\begin{array}{c}\text { Specificity } \\
(\%)\end{array}$ \\
\hline \multirow[b]{2}{*}{ Antibody based } & $d_{-}$ELISA & \multirow[b]{2}{*}{ Indigenous plate ELISA } & $<0.0001$ & $\begin{array}{c}0.547 \pm \\
0.065\end{array}$ & Moderate & $100 \%$ & $69.1 \%$ \\
\hline & LAT & & $<0.0001$ & $\begin{array}{c}0.533 \pm \\
0.072\end{array}$ & Moderate & $88.8 \%$ & $74.2 \%$ \\
\hline \multirow{2}{*}{ Antigen based } & i_FAT & \multirow[b]{2}{*}{ Microscopy } & $<0.0001$ & $\begin{array}{c}0.633 \pm \\
0.063\end{array}$ & Good & $96.4 \%$ & $69.7 \%$ \\
\hline & IS900 PCR & & $<0.0001$ & $\begin{array}{c}0.234 \pm \\
0.060\end{array}$ & Fair & $21.0 \%$ & $100 \%$ \\
\hline
\end{tabular}

Journal of Experimental Biology and Agriculture Science http://www.jebas.org 
sample was positive in IS900 PCR. In milk powder percent positivity was highest in i_FAT and microscopy followed by d_ELISA, LAT, i_ELISA and IS900 PCR. Bio-typing of MAP using IS1311 PCR_RE, showed that liquid milk and milk powder were infected exclusively with 'Indian Bison Type' bio-type of MAP (Table 2bi). Whereas, none of the 19 flavoured milk samples was positive in IS900 PCR, therefore could not be bio-typed.

Milk samples (133) were driven from ten market brands (Amul, Ananda, Nestle India, Gyan, Mother dairy, MTR, Namaste India, Nova, Paras and Sanchi) sold in North India. Sample-wise profile was; 100 liquid milk samples from 8 brands (Amul, Ananda, Gyan, Mother dairy, Namaste India, Nova, Paras and Sanchi), 19 flavoured milk from 5 brands (Amul, Mother dairy, MTR, Paras and Sanchi), and 14 milk powder from two market brands (Amul and Nestle, India). Of the eight market brands of 'liquid milk' screened all were positive for MAP and bio-incidence ranged from 40.0 to $100.0 \%$. Sample size per brand was small except Amul, which is biggest National brand. Of the 8 brands, two were government (Mother's dairy, New Delhi and Sanchi, MAP dairy) and 6 were private (Amul, Ananda, Gyan, Namaste India, Nova and Paras) brands. Screening of 60 liquid milk sample of Amul, $61.6 \%$ were positive for bio-incidence of MAP in multiple tests. Of these 100 liquid milk samples bio-typed, 6.0\% were 'Indian Bison Type' and was dominant bio-type in domestic livestock (Singh et al., 2014) (Table 2). Of 19 flavoured milk (5 milk brands) screened all 5 were positive (bio-incidence ranged from 33.3 to $100.0 \%$ ). Total $47.3 \%$ samples from 19 flavoured milk samples were positive but none could be bio-typed (Table 2bii). In milk powder (14 samples from 2 market brands), $78.5 \%$ samples were positive and $14.2 \%$ bio-typed as 'Indian Bison Type'. Of the 5 milk powder from 2 brands; $80.0 \%$ from (Amul), were positive and none could be bio-typed. Among the collected 9 milk powder samples (Nestle India, International brand), $77.7 \%$ were positive and $22.2 \%$ bio-typed as 'Indian Bison Type' (Table 2biii). Since MAP is secreted in the milk and feces of infected animals (Stable \& Lambertz, 2004), therefore, bioincidence of MAP was very high $\{63.1 \%$ (range 40.0 to $100.0 \%$ ) $\}$ in commercial milk (liquid milk, flavoured milk and milk powder) made from pasteurized milk and sold by leading Indian market brands (Table 2) was due to high bio-load of MAP in the domestic livestock population (Singh et al., 2014). In the absence of control measures, this study using milk based 'indigenous ELISA kit, reported significant high bio-load of MAP in the domestic livestock species in past 2-3 years. Screening of milk samples of domestic livestock using ELISA kit, bio-load of MAP in 'raw milk samples' was also high (25.0-60.0\%) (un-published data of our lab). Earlier studies also reported high bio-load of MAP in domestic livestock using milk and it was 58.2 to $70.1 \%$ in goats (Kumar et al., 2008), $32.1 \%$ in cattle (Sharma et al., 2008) and $46.8 \%$ in buffaloes (Yadav et al., 2008). Since MAP is not inactivated during pasteurization (Lund et al., 2002), therefore to reduce contamination of MAP in milk and milk products it is essential to control infection in animals. Presence of same bio-type (Indian Bison Type) in animals (>95.0\%) and $100.0 \%$ milk and milk products, confirmed high bio-load of MAP in milk and milk products and also role of milk in transmission of MAP to human population (Singh et al., 2009; Singh et al., 2010; Narnaware et al, 2016).

In Indian conditions, collection of blood and harvesting of serum from cattle and buffaloes in the field is difficult primarily due to reluctance of owner, lack of proper restraining equipments and expertise. However, it is very convenient to collect milk samples from lactating cattle and buffaloes. Since Mycobacteria including MAP are secreted through milk (Fiorentino et al., 2012; Salem et al., 2013), therefore, by screening of milk samples (pasteurized liquid milk and milk products) sold in the local markets (Mathura (Farah and Kosi) and Agra districts $\}$ in North India under different brands gave fair estimation of bio-incidence of MAP in the lactating domestic livestock. In our previous studies we used only 4 tests for the screening of milk samples (microscopy, ELISA, culture and IS900 PCR) on very limited number of samples. However, in the present study we evaluated six tests, so as to identify merits of different tests in terms of simplicity, sensitivity and cost effectiveness as screening tests for mass screening of commercial milk samples at field level.

Though these milk samples were prepared from pasteurized milk, due to their waxy cell wall, MAP survive pasteurization by forming clumps due to heating. It has been shown that viable MAP can be detected even after application of different levels of pressure in conjunction with pasteurization (Donaghy et al., 2007). Published reports proved the existence of MAP in non-pasteurized, pasteurized milk, colostrums, milk powder and all types of fresh cheese (Donaghy et al., 2010; Bradner et al., 2013; Botsaris et al., 2016; Eftekhari \& Mosavari, 2016). The fact that these bacteria not only survive pasteurization temperature, but also further processing steps during the production of milk powder is expected due to heavy bio-load of MAP.. Grant et al. (2002) found that the probability of the organism surviving pasteurization may be related to variation in the number of MAP cells present in different batches of raw milk. Hence, presence of MAP in milk powder may be the result of very high contamination levels in the milk samples screened or due to some other conditions, unidentified role of underlying physiological factors or mechanism of survival, such as the possibility of production of spore-like structures (Lamont et al., 2012). It has been suggested that milk powder may be a significant route of exposure of human infants to MAP (Hruska et al., 2011) and there is a concern that large numbers of Mycobacterial cells could act as a pro-inflammatory trigger in premature babies and bottle-fed newborns even if no infection is established (Atreya et al., 2014). 
Cultivable MAP bacilli have been reported from milk based food items (ice creams, cheese, pasteurized milk, milk powder etc) world-wide (Grant et al., 2002; Grant, 2006). In India, viable MAP was detected in pasteurized commercial milk and milk products for the first time by Shankar et al. (2010), when 43 samples (16 unpasteurized, 27 pasteurized) purchased in Mathura, Agra, or New Delhi, were tested for the presence of MAP by culture or by PCR for IS900 MAP DNA. During their study, of the unpasteurized samples, 44.0 and $6.0 \%$ were positive for MAP infection in culture and IS900 PCR, respectively. Whereas, of the pasteurized samples, 67.0 and $33.0 \%$ were MAP positive in culture and IS900 PCR, respectively. Subsequently, $100.0 \%$ of the cultured colonies were IS900 and IS1311 MAP DNA-positive. Positive results were confirmed as MAP 'Bison type' by restriction endonuclease analysis and/or DNA sequencing (Shankar et al., 2010). Recently, MAP has been detected from $22.0 \%$ samples of powdered infant milk using Direct IS900 PCR (Botsaris et al., 2016). In present study, we also observed almost similar results by Direct IS900 PCR, where MAP bacilli were detected in $23.1 \%$ (3/13) of powdered milk samples. Other study revealed $2.8 \%$ (2/70) of samples were positive for MAP in pasteurized and ultra-pasteurized milk samples (Paolicchi et al., 2012).

These data suggests the high bio-incidence of MAP in pasteurized commercial milk samples could be due to preparation of these products from the milk of animals with high bio-load of MAP. Killing of the bacteria requires a high temperature like boiling and hence we strongly recommend that either these products should be prepared from boiled milk or should be boiled / cooked properly before consumption. High bio-incidence of MAP in commercial milk samples using multiple tests indicates serious threat to 'public health'. To reduce the bio-incidence in commercial liquid milk and milk products, it is imperative to control MAP infection in domestic livestock, so as to reduce or stop secretion of MAP in the milk. Study showed that situation was alarming and needs urgent attention to save human population and livestock productivity due to MAP infection. Multiple tests (six tests, three each for antigen and antibody detection in milk and milk products) were used to confirm the infection in the absence of culture test. This study comprehensively established high contamination of commercial milk and milk products from leading market brands and sold in the local markets are potential source of infection of MAP to human population in Agra and Mathura districts of Uttar Pradesh, which may lead to some of the major incurable health disorders of autoimmune nature like Inflammatory Bowel Disease, Crohn's Disease, Rheumatoid arthritis, Diabetes type-1 etc.) (Singh et al., 2009; Singh et al., 2016d).

\section{Conclusion}

Study reported high bio-incidence MAP in commercial liquid milk and milk products (flavoured milk and milk powder) made from pasteurized milk belonging to leading market brands and sold in the local markets in Mathura (Farah and Kosi) and Agra districts of Uttar Pradesh in North India. Study emphasized that consumption of milk and milk products was not safe therefore, urgent need of controlling MAP infection in dairy animals in order to reduce contamination of milk and protect consumers from the risk of incurable MAP infection. Of the 6 tests used, i_FAT was most sensitive followed by d_ELISA, LAT, microscopy, i_ELISA and IS900 PCR. Depending on the requirement (convenience, cost, resources, expertise) any of the four tests (i_FAT, microscopy, d_ELISA, LAT), can be employed for the screening of milk and milk products. Since these 4 tests are qualitative, i_ELISA kit being quantitative was better option. Study confirmed MAP as major 'food borne pathogen'.

\section{Acknowledgements}

Authors are thankful to MoFPI and ICAR for providing funds and Director, ICAR-Central Institute for Research on Goats, Makhdoom, Farah for providing laboratory facilities.

\section{Conflict of Interest}

No potential conflict of interest to declare.

\section{References}

Abubakar I, Myhill DJ, Hart AR, Lake IR, Harvey I, Rhodes JM, Robinson R, Lobo AJ, Probert CS, Hunter PR (2007) A case-control study of drinking water and dairy products in Crohn's diseasefurther investigation of the possible role of Mycobacterium avium paratuberculosis. American Journal of Epidemiology 165: 776-83.

Acharya KR, Dhand NK, Whittington RJ, Plain KM (2017) Detection of Mycobacterium avium subspecies paratuberculosis in powdered infant formula using IS900 quantitative PCR and liquid culture media. International Journal of Food Microbiology 257: 1-9.

Annual Report (2017) Department of Animal Husbandry, Dairying \& Fisheries (DADF), Ministry of Agriculture \& Farmers Welfare, Government of India. chapter 1, Overview of Achievement. page no. 6 .

Atreya R, Bulte M, Gerlach GF, Goethe R, Hornef MW, Kohler H, Meens J, Mobius P, Roeb E, Weiss S, Consortium Z (2014) Facts, myths and hypotheses on the zoonotic nature of Mycobacterium avium subspecies paratuberculosis. International Journal of Medical Microbiology 304: 858-867.

Banche G, Allizond V, Sostegni R, Lavagna A, Bergallo M, Sidoti F, Daperno M, Rocca R, Cuffini AM (2015) Application of multiple 
laboratory tests for Mycobacterium avium ssp. paratuberculosis detection in Crohn's disease patient specimens. New Microbiology 38: $357-367$.

Bastida F, Juste RA (2011) Paratuberculosis control: a review with a focus on vaccination. Journal of Immune based Therapies and Vaccines 9: 8.

Botsaris G, Benjamin MC, Swift, Slana I, Liapi M, Christodoulou M, Hatzitofi M, Christodoulou V, Catherine ED, Rees (2016) Detection of viable Mycobacterium avium subspecies paratuberculosis in powdered infant formula by phage-PCR and confirmed by culture. International Journal of Food Microbiology 216: 91-94.

Bradner LK, Laura K, Stabel, Judith R, Beitz, Donald C, Suelee RA (2013) Shedding of Mycobacterium avium subsp. paratuberculosis into milk and colostrum of naturally infected dairy Cows over complete lactation cycles. Animal Industry Report AS 659 ASL R2793.

Bull TJ, McMinn EJ, Sidi-Boumedine K, Skull A, Durkin D, Neild P, Rhodes G, Pickup R, Hermon-Taylor J (2003) Detection and verification of Mycobacterium avium subsp. paratuberculosis in fresh ileocolonic mucosal biopsy specimens from individuals with and without Crohn's disease. Journal of Clinical Microbiology 41: 2915-23.

Chaubey KK, Gupta RD, Gupta S, Singh SV, Bhatia AK, Jayaraman S, Kumar N, Goel A, Rathore AS, Sahzad, Sohal JS, Stephen BJ, Singh M, Goyal M, Dhama K, Derakhshandeh A (2016) Trends and advances in the diagnosis and control of paratuberculosis in domestic livestock. Veterinary Quarterly 36: 203-227.

Cirone K, Morsella C, Romano M, Paolicchi F (2007) Mycobacterium avium subsp. paratuberculosis in food and its relationship with Crohn's disease. Revista Argentina de Microbiologia 39: 57-68.

Collins MT (2002) Interpretation of a commercial bovine paratuberculosis enzyme-linked immunosorbent assay by using likelihood ratios. Clinical and Diagnostic Laboratory Immunology 9: 1367-1371.

Donaghy JA, Johnson J, Rowe MT (2010) Detection of Mycobacterium avium subsp paratuberculosis in cheese, milk powder and milk using IS900 and f57 based PCR assays. Journal of Applied Microbiology 110: 479-489.

Donaghy JA, Linton M, Patterson MF, Rowe MT (2007) Effect of high pressure and pasteurization on Mycobacterium avium ssp. paratuberculosis in milk. Letters in Applied Microbiology 45: 154159.

Eftekhari M, Mosavari N (2016) Isolation and molecular identification of Mycobacterium from commercially available pasteurized milk and raw milk samples collected from two infected cattle farms in Alborz Province, Iran. International Journal of Mycobacteriology 5: S222-S223.

Eltholth MM, Marsh VR, Van Winden S, Guitian FJ (2009) Contamination of food products with Mycobacterium avium paratuberculosis: a systematic review. Journal of Applied Microbiology 107: 1061-71.

Fiorentino MA, Gioffré A, Cirone K, Morsella C, Alonso B, Delgado F, Paolicchi F (2012) First isolation of Mycobacterium avium subsp. paratuberculosis in a dairy goat in Argentina: Pathology and molecular characterization. Small Ruminant Research 108: 133-6.

Garg R, Patil PK, Singh SV, Sharma S, Gandham RK, Singh AV, Filia G, Singh PK, Jayaraman S, Gupta S, Chaubey KK (2015) Comparative evaluation of different test combinations for diagnosis of Mycobacterium avium subspecies paratuberculosis infecting dairy herds in India. BioMedical Research International Doi: $10.1155 / 2015 / 983978$.

Gilardoni LR, Fernández B, Morsella C, Mendez L, Jar AM, Paolicchi FA, Mundo SL (2016) Mycobacterium paratuberculosis detection in cow's milk in Argentina by immunomagnetic separation-PCR. Brazilian Journal of Microbiology 47: 506-12.

Grant I (2006) Occurrence of Mycobacterium avium subsp paratuberculosis in foods and the impact of milk processing on its survival. $8^{\text {th }}$ International Colloquium on Paratuberculosis, Copenhague, Denmark Pp. 276.

Grant IR, Ball HJ, Neill SD, Rowe MT (1996) Inactivation of Mycobacterium paratuberculosis in cow's milk at pasteurization temperatures. Applied Environmental Microbiology 62: 631-636.

Grant IR, Foddai AC, Tarrant JC, Kunkel B, Hartmann FA, McGuirk S, Hansen C, Talaat AM, Collins MT (2017) Viable Mycobacterium avium ssp. paratuberculosis isolated from calf milk replacer. Journal of Dairy Science 100: 9723-35.

Grant IR, Hitchings EIJ, McCartney A, Ferguson F, Rowe MT (2002) Effect of commercial scale high-temperature, short-time pasteurization on the viability of Mycobacterium avium subsp. paratuberculosis in naturally infected cow's milk. Applied Environmental Microbiology 68: 602-607. 
Hruska K, Slana I, Kralik P, Pavlik I (2011) Mycobacterium avium subsp. paratuberculosis in powdered infant milk: F57 competitive real time PCR. Veterinary Medicine Czech 56: 226-230.

Ikonomopoulos J, Pavlik I, Bartos M, Svastova P, Ayele W, Roubal P, Lukas J, Cook N (2005) Detection of Mycobacterium avium subsp. paratuberculosis in retail cheeses from Greece and Czech Republic. Applied Environmental Microbiology 71: 934-8936.

India in business (2008) Investment and technology promotion and energy security. Delhi: Ministry of External Affairs, Government of India.

Khol JL, Kralik P, Slana I, Beran V, Aurich C, Baumgartner W, Pavlik I (2010) Consecutive excretion of Mycobacterium avium subspecies paratuberculosis in semen of a breeding bull compared to the distribution in feces, tissue and blood by IS 900 and F57 quantitative real-time PCR and culture examinations. Journal of Veterinary Medical Science 72: 1283-8.

Kumar S, Singh SV, Sevilla I, Singh AV, Whittington RJ, Juste RA, Sharma G, Singh PK, Sohal JS (2008) Lacto-prevalence, genotyping of Mycobacterium avium subspecies paratuberculosis and evaluation of three diagnostic tests in milk of naturally infected goatherds. Small Ruminants Research 74: 37-44.

Lamont EA, Bannantine JP, Armien A, Ariyakumar DS, Sreevatsan $S$ (2012) Identification and characterization of a spore-like morphotype in chronically starved Mycobacterium avium subsp. paratuberculosis cultures. PLoS One 7: e30648.

Lund BM, Gould GW, Rampling AM (2002) Pasteurization of milk and the heat resistance of Mycobacterium avium subsp. paratuberculosis: a critical review of the data. International Journal of Food Microbiology 77: 135-45.

McFadden J, Collins J, Beaman B, Arthur M, Gitnick G (1992) Mycobacteria in Crohn's disease: DNA probes identify the wood pigeon strain of Mycobacterium avium and Mycobacterium paratuberculosis from human tissue. Journal of Clinical Microbiology 30: 3070-3.

McNees AL, Markesich D, Zayyani NR, Graham DY (2015) Mycobacterium paratuberculosis as a cause of Crohn's disease. Expert Review of Gastroenterology \& Hepatology 9: 1523-34.

Millar D, Ford J, Sanderson J, Withey S, Tizard M, Doran T, Hermon-Taylor J (1996) IS900 PCR to detect Mycobacterium paratuberculosis in retail supplies of whole pasteurised cows' milk in England and Wales. Applied Environmental Microbiology 62: 3446-3452.
Narnaware SD, Periasamy S, Tripathi BN (2016) Studies on pathology, cytokine gene expression and molecular typing of Mycobacterium avium subsp. paratuberculosis of naturally occurring Johne's disease in bullocks. Research in Veterinary Science 106: 74-80.

Naser SA, Sagramsingh SR, Naser AS, Thanigachalam S (2014) Mycobacterium avium subspecies paratuberculosis causes Crohn's disease in some inflammatory bowel disease patients. World Journal of Gastroenterology 20: 7403.

Nielsen SS, Toft N (2014) Bulk tank milk ELISA for detection of antibodies to Mycobacterium avium subsp. paratuberculosis: correlation between repeated tests and within-herd antibodyprevalence. Preventive Veterinary Medicine 113: 96-102.

Paolicchi F, Cirone K, Morsella C, Gioffre A (2012) First isolation of Mycobacterium avium subsp paratuberculosis from commercial pasteurized milk in Argentina. Brazilian Journal of Microbiology 43: 1034-1037.

Patel A, Shah N (2011) Mycobacterium avium subsp paratuberculosis-Incidences in milk and milk products, their isolation, enumeration, characterization, and role in human health. Journal of Microbiology, Immunology and Infection 44: 473-9.

Pithua P, Wells SJ, Godden SM (2011) Evaluation of the association between fecal excretion of Mycobacterium avium subsp paratuberculosis and detection in colostrum and on teat skin surfaces of dairy cows. Journal of the American Veterinary Medical Association 238: 94-100.

Raghuvanshi T, Singh SV, Sharma RB, Gupta S, Chaubey KK, Kumar N, Dhama K (2014) A pilot study on the presence of Mycobacterium avium subspecies paratuberculosis in fresh cheese (paneer) prepared from goat milk of herds endemic for Johne's disease. Journal of Infection and Molecular Biology 1: 46-48.

Rawat KD, Chaudhary S, Kumar N, Gupta S, Chaubey KK, Singh SV, Dhama K, Deb R (2014) Economic losses in a commercial dairy farm due to the outbreak of Johne's disease in India. Research Journal for Veterinary Practitioners 2: 73-77.

Salem M, Natur S, El-Sayed AA, Hassan A, Baljer G, Zschöck M (2013) Molecular characterization of Mycobacterium avium subsp. paratuberculosis field isolates recovered from dairy cattle in Germany. International Journal of Veterinary Science and Medicine 1: $30-5$.

Scanu AM, Bull TJ, Cannas S, Sanderson JD, Sechi LA, Dettori G, Zanetti S, Hermon-Taylor J (2007) Mycobacterium avium subspecies paratuberculosis infection in cases of irritable bowel syndrome and comparison with Crohn's disease and Johne's disease: 
common neural and immune pathogenicities. Journal of Clinical Microbiology 45: 3883-90.

Sevilla IX, Singh SV, Garrido JM, Aduriz G, Rodriguez S, Geijo MV, Juste RA (2005) Molecular typing of Mycobacterium avium subspecies paratuberculosis strains from different hosts and regions. Revue Scientifique et Technique-Office International des Epizooties 24: 1061.

Shankar H, Singh SV, Singh PK, Singh AV, Sohal JS, Greenstein RJ (2010) Presence, characterization, and genotype profiles of Mycobacterium avium subspecies paratuberculosis from unpasteurized individual and pooled milk, commercial pasteurized milk, and milk products in India by culture, PCR, and PCR-REA methods. International Journal of Infectious Diseases 14: 121-126.

Sharma G, Singh SV, Sevilla I, Singh AV, Whittington RJ, Juste RA, Vihan VS (2008) Evaluation of indigenous milk ELISA with m-culture and m-PCR for the diagnosis of Bovine Johne's disease (BJD) in lactating Indian dairy cattle. Research in Veterinary Science 84: 30-37.

Singh AV, Chauhan DS, Singh SV, Kumar V, Singh A, Yadav A, Yadav VS (2016d) Current status of Mycobacterium avium subspecies paratuberculosis infection in animals and humans in India: What needs to be done?. The Indian Journal of Medical Research 144: 661.

Singh AV, Singh SV, Makharia GK, Singh PK, Sohal JS (2008) Presence and characterization of Mycobacterium avium subspecies paratuberculosis from clinical and suspected cases of Crohn's disease and in the healthy human population in India. International Journal of Infectious Diseases 12: 190-197.

Singh AV, Singh SV, Singh PK, Sohal JS (2010) Genotype diversity in Indian isolates of Mycobacterium avium subspecies paratuberculosis recovered from domestic and wild ruminants from different agro-climatic regions. Comparative Immunology, Microbiology and Infectious Diseases 33: e127-31.

Singh SV, Kumar N, Chaubey KK, Gupta S, Rawat KD (2013b) Bio-presence of Mycobacterium avium subspecies paratuberculosis infection in Indian livestock farms. Research Opinions in Animal \& Veterinary Sciences 3: 401-406.

Singh SV, Singh AV, Singh R, Sandhu KS, Singh PK, Sohal JS, Gupta VK, Vihan VS (2007) Evaluation of highly sensitive indigenous milk ELISA kit with fecal culture, milk culture and fecal-PCR for the diagnosis of bovine Johne's disease (BJD) in India. Comparative Immunology, Microbiology \& Infectious Diseases 30: 175-86.
Singh SV, Singh PK, Gupta S, Chaubey KK, Singh B, Kumar A, Singh AV, Kumar N (2013a) Comparison of microscopy and bloodPCR for the diagnosis of clinical Johne's disease in domestic ruminants. Iranian Journal of Veterinary Research 14: 345-9.

Singh SV, Singh PK, Singh AV, Sohal JS, Kumar N (2014) Bioload and bio-type profiles of Mycobacterium avium subspecies paratuberculosis infection in the domestic livestock population endemic for Johne's disease: A survey of 28 years (1985-2013) in India. Transboundary and Emerging Diseases 61: 43-55.

Singh SV, Sohal JS, Singh PK, Singh AV (2009) Genotype profiles of Mycobacterium avium subspecies paratuberculosis isolates recovered from animals, commercial milk, and human beings in North India. International Journal of Infectious Diseases 13: e221-7.

Singh SV, Stephen BJ, Singh M, Gupta S, Chaubey KK, Sahzad, Jayaraman S, Sachan TK, Aseri GK, Jain M, Sohal JS, Dhama K (2016a) Evaluation of Indirect Fluorescent Antibody Test (i_FAT) as the 'mass screening test' for the diagnosis of Mycobacterium avium subspecies paratuberculosis infection in the milk samples of lactating domestic livestock. Journal of Experimental Biology and Agricultural Sciences 4: 533-540.

Singh SV, Stephen BJ, Singh M, Gupta S, Chaubey KK, Sahzad, Jayaraman S, Aseri GK, Sohal JS, Bhatia AK, Chauhan J, Dhama K (2016b) Evaluation of milk dot-ELISA as field based test vis a vis milk plate ELISA for the detection of Mycobacterium avium subspecies paratuberculosis (MAP) in lactating domestic livestock. Indian Journal of Biotechnology 15: 166-171.

Singh SV, Stephen BJ, Singh M, Gupta S, Chaubey KK, Sahzad, Jayaraman S, Sachan TK, Sohal JS, Dhama K, Mukartal SY, Hemati Z (2016c) Comparison of newly standardized 'Latex milk agglutination test', with 'Indigenous milk ELISA' for 'on spot' screening of domestic livestock against Mycobacterium avium subsp. paratuberculosis infection. Indian Journal of Biotechnology 15: 511-517.

Stabel JR, Lambertz A (2004) Efficacy of pasteurization conditions for the inactivation of Mycobacterium avium subsp. paratuberculosis in milk. Journal of Food Protection 67: 2719-26.

Stabel JR, Wells SJ, Wagner BA (2002) Relationships between fecal culture, ELISA and bulk tank milk results for Johne's disease in US dairy herds. Journal of Dairy Science 85: 525-531.

Stephan R, Buhler K, Corti S (2002) Incidence of Mycobacterium avium subsp. paratuberculosis in bulk-tank milk samples from different regions of Switzerland. Veterinary Records 150: 214-215.

Tursun D, Shi YZ, Yang QL, Liu Y, Xue WC, Abas A, Yang WJ (2015) Influence on Strychni Semen's Analgesic Effect and Toxicity

Journal of Experimental Biology and Agriculture Science http://www.jebas.org 
of Milk-Impregnated- Processing-Technology of Traditional Uighur Medicine. Zhong Yao Cai 38: 267-70.

van Soolingen D, Hermans PW, de Haas PE, Soll DR, van Embden JD (1991) Occurrence and stability of insertion sequences in Mycobacterium tuberculosis complex strains: evaluation of an insertion sequence-dependent DNA polymorphism as a tool in the epidemiology of tuberculosis. Journal of Clinical Microbiology 29: 2578-2586.

Vary PH, Andersen PR, Green E, Hermon-Taylor J, McFadden JJ (1990) Use of highly specific DNA probes and the polymerase chain reaction to detect Mycobacterium paratuberculosis in Johne's disease. Journal of Clinical Microbiology 28: 933-937.
Whittington RJ, Lloyd JB, Reddacliff LA (2001) Recovery of Mycobacterium avium subsp. paratuberculosis from nematode larvae cultured from the feces of sheep with Johne's disease. Veterinary Microbiology 81: 273-279.

Whittington RJ, Windsor PA (2009) In utero infection of cattle with Mycobacterium avium subsp.paratuberculosis: a critical review and meta-analysis. The Veterinary Journal 179: 60-69.

Yadav D, Singh SV, Singh AV, Sevilla I, Juste RA, Singh PK, Sohal JS (2008) Pathogenic 'Bison-type' Mycobacterium avium subspecies paratuberculosis genotype characterized from riverine buffalo (Bubalus bubalis) in North India. Indian Journal of Comparative Microbiology, Immunology and Infectious Diseases 31: 373-387. 